\title{
Differential etching after lithic heat treatment: First results of an experimental study
}

\author{
Linda Kiers \\ Kostvlies 2, 9462 TR Gasselte, The Netherlands. Email: lindakiers@yahoo.co.uk
}

\begin{abstract}
:
The practice of lithic heat treatment creates a combination of initial dull flake scars and subsequent smooth flake scars when the implement is finished after heating. Experiments were done to test the susceptibility of dull and smooth flake scars to etching. The points were etched in $40 \%$ hydrofluoric acid for either 40 or 60 seconds. In the 40 seconds experiment, the smooth flake scars of 9 (out of 25) heated points showed less etching than the dull flake scars or no etching at all. These artefacts formed a weathering pattern that is similar to double patina in reworked flints. Ten unheated control samples did not form differential weathering between different generations of flake scars. In the 60 seconds experiment 4 (out of 25) heated points showed some parts of the smooth surface to be less affected. Ten unheated control samples did not form differential weathering. The experiments show that sometimes smooth flake scars are more resistant to etching initially.

In Scanning Electron Microscopy, flint artefacts are sometimes pre-treated with hydrofluoric acid. Heat treated flints are susceptible to differential weathering by hydrofluoric acid. Thus, pretreatment with hydrofluoric acid of heat treated SEM samples can lead to surfaces that are etched to a different extent.

The chemical etching in this study does not replicate any natural patination process. How heat treated lithics respond to natural weathering processes cannot be predicted. Further studies should produce natural patination and test selected artefacts in contexts of intentional heat treatment for signs of heating.
\end{abstract}

Keywords: heat treatment; artificial patination; differential weathering; SEM-sampling

\section{Introduction}

Heat treatment is a technological process in which siliceous stone is heated so as to increase suitability for knapping. Slight heating enhances structure and as a result flaking properties are enhanced (see Luedtke 1992: 103-104). Prehistoric examples have been found in various parts of Africa (Brown et al. 2009, Domański \& Webb 2007; Delagnes et al. 2016), Asia (Domański \& Webb 2007; Inizan et al. 1977; Nadel 1989; Zhou et al. 2013), Australia (Domański \& Webb 2007; Flenniken \& White 1983), North-America (Luedtke 1992), South America (Domański \& Webb 2007; Frank 2004), and Europe. Within Europe, heat treatment has been applied in France (Aubry et al. 2003; Collins 1973; Gawel \& Weiner 2010; Schmidt

Published by the School of History, Classics and Archaeology, University of Edinburgh ISSN: 2055-0472. URL: http://journals.ed.ac.uk/lithicstudies/ 
et al. 2013), Germany (Eriksen 1997; Heinen 2005), Italy (Santaniello et al. 2016), Portugal (Aubry et al. 2003), Poland (Domański et al. 2009), and Spain (Tiffagom 1998).

When heat treatment has been applied successfully, the surfaces of subsequent flake scars will be smoother (Olausson \& Larsson 1982). It is probable that the degree of chemical weathering of the dull and the shiny surfaces differs, since, according to Keeley (1980: 29), patination processes affect smooth surfaces less. A differential weathering effect may be postulated upon 1) chemical etching as pre-treatment of SEM samples, and, 2) natural weathering processes such as patination. Therefore, it is possible that on a macro-scale heat treatment results in differential weathering with a pattern identical to double patina. Double patina is the term used to describe the occurrence of both patinated flake scars and flake scars that are unpatinated or less patinated on a single artefact (Goodwin 1960). Double patina develops when a patinated artefact is reworked (Goodwin 1960).

In order to recognise more cases of heat treatment, it is important to test whether the dull and the smooth flake scars are affected differently by various chemical and biological weathering processes. Additionally, in order to exclude influence on SEM pre-treatment it is important to test the effect of chemical etching on shiny and dull surfaces. This paper will report on an initial experiment focusing on chemical etching of heat treated artefacts. The chemical etching is done with hydrofluoric acid which is also used in the pre-treatment of SEM samples. The results of the chemical etching cannot be extended to natural patination processes.

\subsection{Heat treatment}

Successful heat treatment results in a raw material with improved flaking properties for pressure flaking. The temperature at which the siliceous rock is heated must be sufficiently high to realize the transformation, while at the same time heat damage should be prevented. Suitable temperature ranges vary between different siliceous rocks and flint varieties. For example Knife River flint responded best to temperatures of $225-250{ }^{\circ} \mathrm{C}$ (Ahler 1983) while $350{ }^{\circ} \mathrm{C}$ is most beneficial for Grand Pressigny flint (Inizan et al. 1977). According to Mercieca and Hiscock (2008) a treshold temperature for different siliceous rock types cannot be established, because this is influenced by the size and shape of the specimen.

The structural change is the result of a chemical reaction that involves the loss of silanol in the chalcedony (Schmidt et al. 2012). Due to the loss of silanol hardness increases and this is a likely cause of altered flaking properties (Schmidt et al. 2012). Thus, the smoothness of newly formed fractures in comparison to older fractures of heat-treated artefacts is related to a change in crystallography induced by the loss of silanol during heating.

\subsection{Differential weathering}

Patination can affect both a segment of and the entire surface of a stone. Goodwin describes three patterns in which patina can be found on artefacts: double patina, differential patina, and anachronistic patina (patina that is found on old surfaces). Artefacts that exhibit double patina possess an older generation of flake scars that have been patinated and a younger generation of flake scars that are not or less patinated. This pattern formed as a result of reworking an old patinated artefact in order to reuse it. In the case of differential patina, the degree of patina differs across the entire surface (Goodwin 1960: 68).

Differential patina can form as a result of differences in exposure to the patinating process. Differential patina can also be a result of variations in the stone itself, for example of the structure and composition of the stone (Hurst \& Kelly 1961). Keeley experimented with working edges with microwear polish and concluded these are less susceptible to patination. 
Owing to the smooth surface of the microwear polish, there is relatively less surface that can react chemically (Keeley 1980: 29).

\section{Methodology}

\subsection{Experimental heat treatment}

The first step to test the hypothesis is experimentally creating intentionally heated artefacts, in this case points, that can then be etched. Firstly, in order to accomplish this, roughouts were created by T. van Grunsven and E. Mols. Flints from the type sites of GrandPressigny, Ryckholt, Valkenburg, Świeciechów, Eben-Emael, and Bergerac were used. Additionally fine-grained flint from Denmark, fine-grained flint from the Charente (Fr.), and four varieties of fine-grained flint from the North Sea were used. Flint is defined here as biogenic cryptocrystalline quartz with conchoidal fracturing. The roughouts were heated in a kiln, imbedded in sand. The kiln was stepwise heated to $350^{\circ} \mathrm{C}$ over the course of 9.5 hours and then left to cool for a day. This heating method was developed by flint knapper T. van Grunsven; in his experience it gives good results for all types of flints.

The roughouts were then further chipped to finished points by means of pressure retouch. The roughouts were worked into 74 points by a group of flint knappers. Furthermore, they made 25 points from unheated roughouts that will serve as control samples. The heat treatment was successful, as flaking appeared to be easier after heat treatment and the new flake scars showed a glossy surface, which indicates structural change. The difference in surface microstructure of flake scars before and after the heat treatment, often illustrated with SEM images, can also be illustrated with acetate peels (Figure 1). Acetate peel technique allows for the creation of a highly detailed replica of surface textures.

The surface roughness of each flint type was measured on dull and smooth flake surfaces of heated points. The measurements were taken by J. Kroon who used an optical profilemeter (Perthometer M3a).In half of the specimens the surface roughness (measured as $R_{a}$ ) of the flake scars after heating is increased rather than decreased (Table 1). This can be explained by considering that post-heating fractures can be more splintery, while their texture is smoother. Because the $\mathrm{R}_{\mathrm{a}}$ profile reflects both the increased ridges and the smoother texture, outcomes between samples can vary. An illustration of increased smoothness can be found in Figure 1.

Before and after etching colours were recorded with Munsell soil charts (1975). One specimen showed colour differences between the dull and smooth flake scars after heating. Presumably, during heating minerals in the surface have darkened and this surface was partially removed by flaking.

\subsection{Experimental etching}

The focus of the experimental programme is the chemical etching of heat treated flints with hydrofluoric acid. Hydrofluoric acid can cause an alteration similar to white patina on flint (Stapert 1976) and quartz (Bäsemann 1987: 7). When hydrofluoric acid is dripped onto flint, a whitening of the surface will show within seconds. The chemical reactions for the etching of silicon dioxide in hydrofluoric acid solutions $\left(\mathrm{SiO}_{2}+6 \mathrm{HF} \rightarrow 2 \mathrm{H}_{2} \mathrm{O}+\mathrm{H}_{2} \mathrm{SiF}_{6}\right)$ and their kinetics are discussed in Monk et al. (1993). This etching is not a good parallel for natural patination processes, so any observations cannot be extended to natural patination.

The experimental points were submerged in a $40 \%$ solution of hydrofluoric acid by $\mathrm{H}$. de Kruijk. Twenty-five heated and ten unheated control specimens were submerged for 40 seconds; another twenty-five heated and ten unheated control specimens were submerged for 60 seconds. Afterwards, any remaining acid was neutralized with ammonium hydroxide and the stones were rinsed with water. 


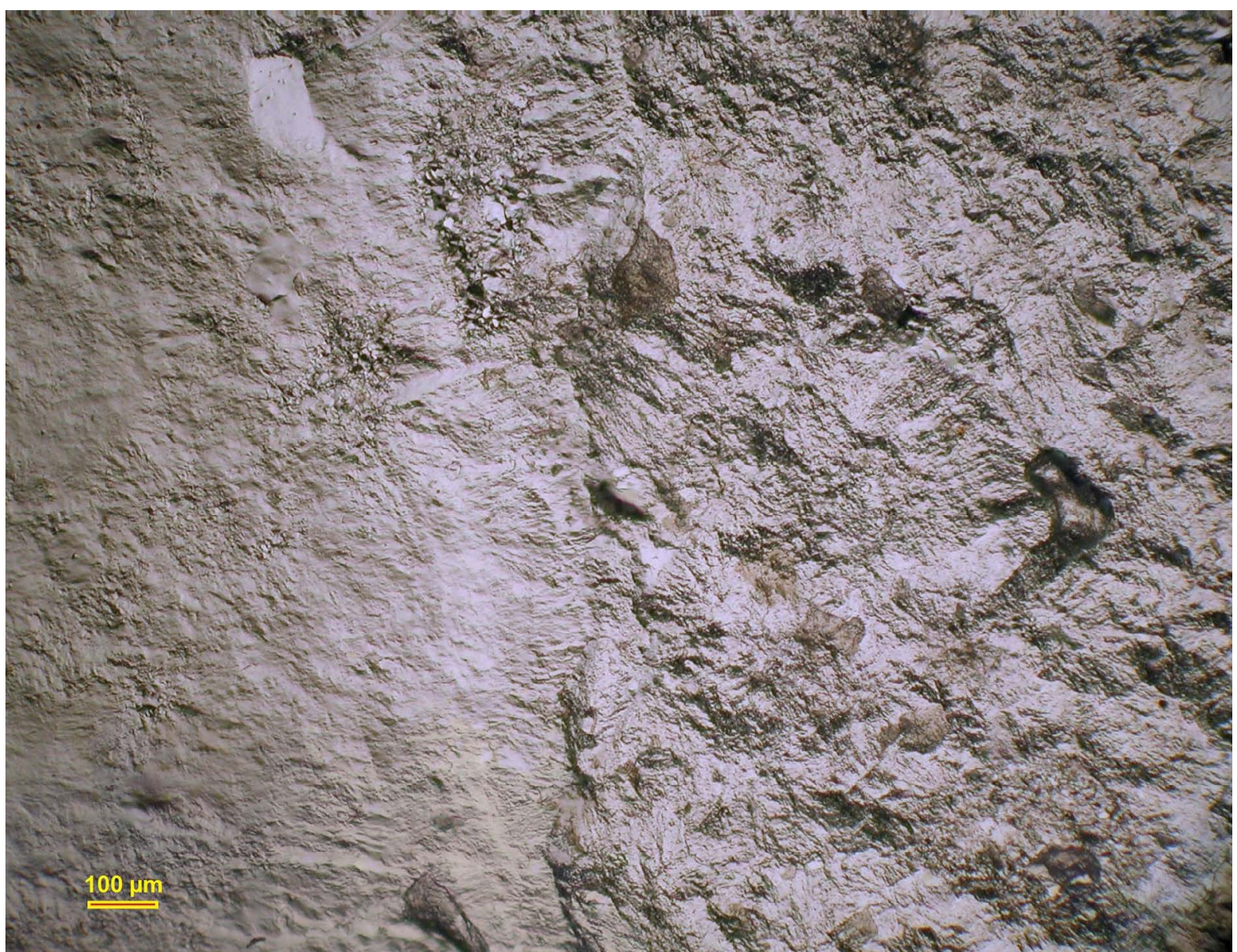

Figure 1. Surface structure of smooth (l) and dull surface (r) of experimental Grand-Pressigny point. The micrograph is prepared using a dark field mask with a slit in the middle to create both scattered and directly transmitted light (photo and acetate peel H. de Kruijk).

Table 1. Surface roughness measurements of twelve heated points (settings: $R_{a}=3, R_{t}=10$, scale range 0.8-4.8 mm).

\begin{tabular}{lccc}
\hline Flint type & $\mathbf{R}_{\mathbf{a}}$ pre-heating & $\mathbf{R}_{\mathbf{a}}$ post-heating & Outcome patina type \\
\hline Bergerac & 1.8 & 1.74 & double $(\mathrm{hf} 40 \mathrm{~s})$ \\
Charente & 2.2 & 0.8 & all over $(\mathrm{hf} 60 \mathrm{~s})$ \\
Eben-Emael & 1.35 & 1.5 & all over $(\mathrm{hf} 60 \mathrm{~s})$ \\
Grand-Pressigny & 1.85 & 2.1 & all over $(\mathrm{hf} 60 \mathrm{~s})$ \\
Northsea 1 & 2.2 & 1 & double $(\mathrm{hf} 40 \mathrm{~s})$ \\
Northsea 2 & 1.4 & 1.35 & in-between $(\mathrm{hf} 40 \mathrm{~s})$ \\
Northsea 3 & 1.4 & 2 & in-between $(\mathrm{hf} 60 \mathrm{~s})$ \\
Northsea 4 & 1.6 & 2.3 & double $(\mathrm{hf} 40 \mathrm{~s})$ \\
Ryckholt & 1.45 & 1.9 & all over $(\mathrm{hf} 40 \mathrm{~s})$ \\
Scandinavian & 2.35 & 1.55 & all over $(\mathrm{hf} 40 \mathrm{~s})$ \\
Świeciechów & 0.8 & 1.3 & all over $(\mathrm{hf} 40 \mathrm{~s})$ \\
Valkenburg & 1.6 & 1.4 & double $(\mathrm{hf} 40 \mathrm{~s})$ \\
\hline
\end{tabular}

\section{Results}

Nine of the heat-treated points that were etched for 40 seconds show double patina (Figure 2; Table 2). Two show a form of patina in-between double patina and overall white patina: some but not all of the smoother surfaces are less altered. The dull surfaces have 
developed white patina; the smooth surfaces have retained unpatinated or less patinated surface but patina 'bleeds' across the edges of the smooth retouches. None of the heat-treated points etched for 60 seconds show double patina. Four show patina in-between double patina and overall patina. None of the unheated points developed double patina or the in-between form.

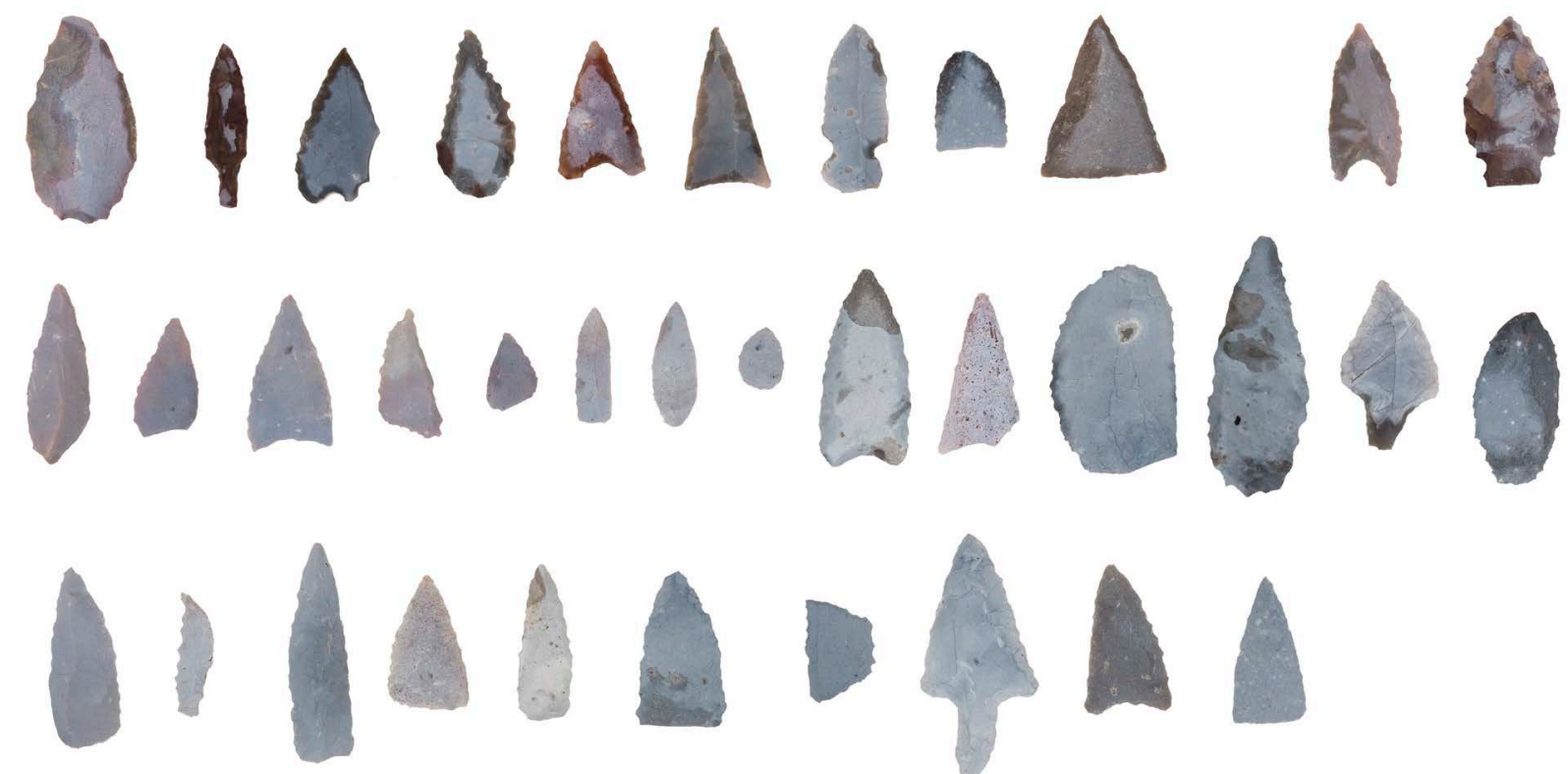

Figure 2. Experimental points after 40 seconds HF. Upper row left: double patina (heated); upper row right: inbetween patina (heated); middle row: white patina (heated); lower row: white patina (unheated) (photo D. Fennema).

Table 2. Results of experiments with hydrofluoric acid. Abbrevations: $B=B e r g e r a c ; C=C h a r e n t e ; ~ E=E b e n-$ Emael; GP=Grand-Pressigny; N1/2/3/4=Northsea 1/2/3/4; R=Ryckholt; Sc=Scandinavian; Św= Świeciechów; $\mathrm{V}=$ Valkenburg.

\begin{tabular}{llll}
\hline & Double & In-between & All over \\
\hline HF 40 s-heated & B, GP, N1, N3, N4, & B, N2 & B, B, B, B, B, C, C, C, E, GP, R, R, Sc, Św \\
& Sc, Sc, Św, V & & \\
HF 40 s- unheated & & N3, N4, R, Sc & B, C, C, GP, N2, R, R, Sc, Św, V \\
HF 60 s- Beated & & N2, B, C, C, C, C, E, GP, GP, GP, N1, \\
& & B, B, C, C, E, N4, R, R, Sc, Św \\
HF 60 s- unheated & &
\end{tabular}

Because double patina developed only in the shorter exposure group, it can be suspected that more heated points would have developed double patina with shorter exposure times. This has not been tested because short exposure times, for example 5 seconds, result in faint patinas that are barely visible in photographs. From the experiments with hydrofluoric acid it can be concluded that the smoother surfaces of heat treated flints frequently develop less weathering due to chemical etching in comparison to their dull surfaces, but this effect occurs only in the earlier stages.

\section{Discussion and conclusion}

In this study, the hypothesis that smooth flake scars that formed after heat treatment respond differently to chemical etching than dull flake scars was tested experimentally. Upon etching with HF smooth flake scars sometimes are affected less than dull flake scars. This effect, however, disappears after prolonged etching. 
Artificial patination with HF does not imitate natural patination processes. Future experiments should address natural white patination, patination processes by lithobionts and patinas that are formed by infiltration or oxidation or both infiltration and oxidation.

The relevance of the effect of differential weathering possibly extends to other artefacts that have not been subjected to intentional heat treatment. Fracture surfaces that are a result of accidental heat treatment and heat fractures that formed after the loss of silanol are also smoother and possibly more resistant to weathering. For example, some burnt artefacts from Gönnersdorf developed white patina except on the surfaces of heat fractures (Franken \& Veil 1983: 325).

The pattern of the differential weathering that can develop on heat treated flint is identical to the double patina that forms when old, patinated flints are reworked. Since these two different types of differential weathering have different causes, it is possible to determine the exact cause by means of methods from natural science. For example, Scanning Electron Microscopy is a suitable method for examining differences in surfaces, and Electron Spin Resonance spectroscopy (ESR) can be used to test whether a stone has been burnt (Griffiths et al. 1986; Robins et al. 1978; 1981). A simple method is to compare colour and flaking properties before and after heating (Flenniken \& White 1983). In the case of flint (Borradaile et al. 1993) and silcrete (Rowney and White 1997), burning can be proved by using magnetic detecting methods. Lastly, several methods using infrared spectroscopy have been developed to test if a flint was heated (Schmidt et al. 2013; Weiner et al. 2015; Santaniello et al. 2016)..

To study the structural change accompanying heat treatment, archaeologists have compared SEM-images of dull flake scars and lustrous flake scars. The SEM-samples are regularly pre-treated with hydrofluoric acid. Nevertheless, the smooth surfaces are sometimes initially affected less by this acid. When the samples are chemically treated in identical manner, it can result in SEM-images that not only exhibit differences in surface structures, but also in the extent of etching of the structure. A suspected different reaction to hydrofluoric acid before and after heat treatment has been noted by Schmidt et al. (2012). Differential weathering can possibly explain the more dense structure of smooth surfaces sometimes observed (Purdy \& Brooks 1971).

\section{Acknowledgements}

I would like to thank Ms. I. Hubers, J. Kroon, R. van Minnen and Dr. J.H.M. Peeters for their help of various kind. I am thankful for the comments of two anonymous reviewers. For creating roughouts, points, acetate peels and etching I am especially grateful to $\mathrm{T}$. van Grunsven, E. Mols, the flint knappers of the VAEE and H. de Kruijk. The flint knappers that participated are Ms. M. Blom, A. ten Brink, J. W. van der Drift, E. van Eden, H. Gilissen, T. van Grunsven, A. Hazewinkel, G. Kerkhof, R. Meijer, E. Mols, H. Paas, B. van Rosmalen, J. Snelten, M. Terdu and J. Werschkull.

\section{References}

Ahler, S.A., 1983, Heat treatment of Knife River Flint. Lithic Technology, 12(1): 1-8. URL: http://www.jstor.org/stable/41999761

Aubry, T., M. Almeida, M.J. Neves \& B. Walter, 2003, Solutrean laurel leaf point production and raw material procurement during the Last Glacial Maximum in Southern Europe: Two examples from Central France and Portugal. In: Multiple approaches to the study of bifacial technologies (Soressi, M., \& Dibble, H.L., Eds.), University Museum Monograph Vol. 115. University of Pennsylvania Museum, Philadelphia: p. 165-182. 
Bäsemann, R., 1987, Umweltabhängige Strukturveränderung an Steinartefakten. Arbeiten zur Urgeschichte des Menschen Vol. 10. Lang, Frankfurt am Main, 111 p. (in German) ("Environmentally dependant structural change of lithic artefacts")

Borradaile, G.J., S.A. Kissin, J.D. Stewart, W.A. Ross \& T. Werner, 1993, Magnetic and optical methods for detecting the heat treatment of chert. Journal of Archaeological Science, 20(1): 57-66. doi:10.1006/jasc.1993.1004

Brown, K.S., C.W. Marean, A.I.R. Herries, Z. Jacobs, C. Tribolo, D. Braun, D.L. Roberts, M.C. Meyer \& J. Bernatchez, 2009, Fire as an engineering tool of early modern humans. Science, 325(5942): 859-862. doi:10.1126/science.1175028

Collins, M.B., 1973, Observations on the thermal treatment of chert in the Solutrean of Laugerie Haute, France. Proceedings of the Prehistoric Society, 39: 461-466. doi:10.1017/S0079497X00011774

Delagnes, M., P. Schmidt, K. Douze, S. Wurz, L. Bellot-Gurlet, N.J. Conard, K.G. Nickel, K.L van Niekerk \& C.S. Henshilwood, 2016. Early evidence for the extensive heat treatment of silcrete in the Howiesons Poort at Klipdrift Shelter (layer PBD, 65 ka, South Africa. PLoS ONE, 11(10): p. 27. Accessed: 28-10-2018. doi:10.1371/journal.pone.0163874

Domański, M., \& J. Webb, 2007, A review of heat treatment research. Lithic Technology, 32: 153-194. doi:10.1080/01977261.2007.11721052

Domański, M., J. Webb, R. Glaisher, J. Gurba, J. Libera \& A. Zakościelna, 2009, Heat treatment of Polish flints. Journal of Archaeological Science, 36(7): 1400-1408. doi:10.1016/j.jas.2009.02.002

Eriksen, B.V., 1997, Implications of thermal pre-treatment of chert in the German Mesolithic. In: Man and flint. Proceedings of the VIIth International Flint Symposium Warszawa Ostrowiec Świętokrzyski September 1995, (Schild, R., \& Sulgostowska, Z., Eds.) Polish Academy of Sciences, Warsaw: p. 325-329.

Flenniken, J.J. \& J.P. White, 1983, Heat treatment of siliceous rocks and its implications for Australian prehistory. Australian Aboriginal Studies, 1: 43-48.

Frank, D.A., 2004. Heat treatment of lithic artifacts in early sites from the central Plateau of Santa Cruz (Argentina). In: Southbound. Late Pleistocene peopling of Latin America, (L. Miotti, M. Salemme, N. Flegenheimer \& T. Goebel, Eds.), Peopling of the Americas publications, Center for the study of the first Americans, Texas A\&M University, Bryan: p 4.

Franken, S. \& S. Veil, 1983, Die Steinartefakte von Gönnersdorf, Der Magdalénien-Fundplatz Gönnersdorf 7. Franz Steiner Verlag, Wiesbaden, 437 p. (in German) (“The lithic Artefacts of Gönnersdorf”)

Gawel, R.P. \& J. Weiner, 2010, Einzigartig im Rheinland! Eine Pfeilspitze aus getempertem Feuerstein. Archäologie im Rheinland 2009: 50-52. (in German) ("Unique in Rhineland! An Arrowhead of heat treated Flint”)

Goodwin, A.J.H., 1960, Chemical alteration (patination) of Stone. The South African Archaeological bulletin, 15(59): 67-76. doi:10.2307/3886559

Griffiths, D.R., N.J. Seeley \& M.C.R. Symons, 1986, Investigation of chert heating conditions using ESR spectroscopy. In: The scientific study of flint and chert: Proceedings of the fourth International Flint Symposium held at Brighton Polytechnic, 10-15 april 1983, 
(Sieveking, G. de G., \& Hart, M.B., Eds.), Cambridge University Press, Cambridge: p. 259-262.

Heinen, M., 2005, Sarching '83 und '89/90. Untersuchungen zum Spätpaläolithikum und Frühmesolithikum in Südost-Deutschland. Welt und Erde Verlag, Kerpen-Loogh, 520 p. (in German) ("Sarching '83 and '89/90. Studies of the Late Palaeolithic and Early Mesolithic in Southeastern Germany”)

Hurst, V.J. \& A.R. Kelly, 1961, Patination of cultural flints. Science, 134(3474): 251-256. doi:10.1126/science.134.3474.251

Inizan, M.-L., H. Roche \& J. Tixier, 1977, Avantages d'un traitement thermique pour la taille des roches siliceuses. Quaternaria, 19: 1-18. (in French) ("Benefits of heat treatment for knapping siliceous rocks”)

Keeley, L.H., 1980, Experimental determination of stone tool uses; a microwear analysis. University of Chicago Press, Chicago, 212 p.

Luedtke, B.E., 1992, An archaeologist's guide to chert and flint. Archaeological Research Tools Vol. 7. University of California, Los Angeles, 172 p.

Mercieca, A. \& P. Hiscock, 2008, Experimental insights into alternative strategies of lithic heat treatment. Journal of Archaeological Science, 35(9): 2634-2639. doi:10.1016/j.jas.2008.04.021

Monk, D.J., D.S. Soane \& R.T. Howe, 1993, A review of the chemical reaction mechanism and kinetics for hydrofluoric acid etching of silicon dioxide for surface micromachining applications. Thin Solid Films, 232: 1-12. doi:10.1016/0040-6090(93)90752-B

Munsell, Color (company), 1975, Munsell soil color charts. Munsell Color, Baltimore, 4 p.

Olausson, D.S, \& L. Larsson, 1982. Testing for the presence of thermal pretreatment of flint in the mesolithic and neolithic of Sweden. Journal of Archaeological Science 9: p. 275285.

Nadel, D., 1989, Flint heat treatment at the beginning of the Neolithic period in the Levant. Mitekufat Haeven: Journal of the Israel Prehistoric Society, 22: 61-67. URL: http://www.jstor.org/stable/23373091

Purdy, B.A., \& H. K. Brooks, 1971, Thermal alteration of silica minerals: an archaeological approach. Science, 173(3994): 322-325. doi:10.1126/science.173.3994.322

Robins, G.V., N.J. Seeley, D.A.C. McNeil \& M. R. C. Symons, 1978, Identification of ancient heat treatment in flint artefacts by ESR spectroscopy. Nature, 276: 703-704. doi:10.1038/276703a0

Robins, G.V., N.J. Seeley, M.C.R. Symons \& D.A.C. McNeil, 1981, Manganese (II) as an indicator of ancient heat treatment in flint. Archaeometry, 23(1): 103-107. doi:10.1111/j.1475-4754.1981.tb00960.x

Rowney, M. \& J.P. White, 1997, Detecting heat treatment on silcrete: Experiments with methods. Journal of Archaeological Science, 24(7): 649-657. doi:10.1006/jasc.1996.0147

Santaniello, F., S. Grimaldi, A. Pedrotti \& S. Gialanella, 2016, First evidence of heat treatment during the early Neolithic in northeastern Italy. Quaternary International, 402: 80-89. doi:10.1016/j.quaint.2015.08.006 
Schmidt, P., S. Masse, G. Laurent, A. Slodczyk, E. le Bourhis, C. Perrenoud, J. Livage \& F. Fröhlich, 2012, Crystallographic and structural transformations of sedimentary chalcedony in flint upon heat treatment. Journal of Archaeological Science, 39(1): 135-144. doi:10.1016/j.jas.2011.09.012

Schmidt, P., V. Léa, Ph. Sciau \& F. Fröhlich, 2013, Detecting and quantifying heat treatment of flint and other silica rocks: A new non-destructive method applied to heat-treated flint from the Neolithic Chassey culture, southern France. Archaeometry, 55(5): 794805. doi:10.1111/j.1475-4754.2012.00712.x

Stapert, D., 1976, Some natural surface modifications on flint in the Netherlands. Palaeohistoria, 18: 7-41.

Tiffagom, M., 1998, Témoignages d'un Traitement Thermique des Feuilles de Laurier dans le Solutréen Supérieur de la Grotte de Parpalló (Gandia, Espagne). Paléo, 10: 147-61. (in French) ("Evidence of heat treatment of laurel leaf points in the Upper Solutrean of the Parpalló cave (Gandia, Spain)”)

Weiner, S., V. Brumfeld, O. Marder \& O Barzilai, 2015, Heating of flint debitage from Upper Palaeolithic contexts at Manot Cave, Israel: Changes in atomic organization due to heating using infrared spectroscopy. Journal of Archaeological Science, 54(1): 45-53. doi:10.1016/j.jas.2014.11.023

Zhou, Z.Y., Y. Guan, X. Gao \& C.X. Wang, 2013, Heat treatment and associated early modern human behaviors in the Late Paleolithic at the Shuidonggou site. Chinese Science Bulletin, 58(15): 1801-1810. doi:10.1007/s11434-012-5522-3 